\title{
AN EMPIRICAL VIEW ON VALUE THEORY AND VALUE-BASED MANAGEMENT
}

\section{Marius Costin Daraban ${ }^{1}$}

\begin{abstract}
The main economic purpose of a business organization is to create value for its owner. The value concept is a complex notion that has developed alongside human history and reflects the concerns of human society through time. As a result of the value theory, the management of value has also emerged as an essential and accompanying activity. Value-based management emerged as a management philosophy rather than a management method. It consists of a change in mindset from managing resources or output quantities to value creation. The challenge is to identify or create the value flows and act upon these within the specific business organization to have proper value management. Value creation and value management will define the business organizations in the economy of the $21^{\text {st }}$ century, which is governed by knowledge and information. The present paper focuses on the history and development of the value concept and the history and development of the management of value through value-based management.
\end{abstract}

JEL Classification Numbers: B00, N00, M2, DOI: http://dx.doi.org/10.12955/cbup.v4.740

Keywords: value, value-based management, economic value.

\section{Introduction}

Since the very early beginning of human history, mankind has tried to define and understand the concept of value. Scholars, intellectuals, academics, philosophers, and theorists have also tried to reason and comprehend the term 'value' by understanding how objects attained their value. During this time, different currents of thought have proposed various explanations to the concept of value. Explanations have not always pointed in the same direction. Similar, and alongside the development of the value concept, the management of value has had its fair share of evolvement and gaining of concerns.

\section{History of the value concept}

Value was one of the main concerns from the very early stages of human society development. One of the first philosophers that developed a theory related to the term value was Aristotle who understood that value is driven by certain needs that creates the basis of exchange as one of the very early forms of trade. Artistoles' theory on value was not very thorough or sustained, being part of ethics and philosophy.

A more detailed approach to the concept of value can be found in the $17^{\text {th }}$ century. William Petty (1623-1687) focused on the search for the natural value. His theory is based on the assumption that the market price of any goods or services would fluctuate permanently around its natural value that is based on land and labor, as production factors. Richard Cantillon's (1680-1734) theory of value identified Petty's model and concluded that the core values of any good should be centered on land only.

The value theory continued to develop over time with scholars such as Nicholas Barbon (16401698), who assimilated the natural value of goods for their market price. Ferdinando Galiani (17281787 ) in his theory of value argued that utility defined value.

Adam Smith (1723-1790) published his groundbreaking work "Wealth of Nations" in 1776. In this, he adopted the value theory of Petty to takes it is a step further. Adam Smith was one of the first to define the concept of objective, intrinsic value as the value contained in goods and services.

Smith's theory was adapted and developed in the late $18^{\text {th }}$ and early $19^{\text {th }}$ centuries by David Ricardo and Karl Marx. David Ricardo (1772-1823) investigated Smith's theory and argued that value depended on the time requirements of labor for production.

\footnotetext{
${ }^{1}$ Marius Costin Daraban, Lucian Blaga University of Sibiu, Sibiu, Romania, marius.daraban@ulbsibiu.ro
} 
Fogarty (1996) wrote of this:

More precise and clearer than Smith, Ricardo stated that "Possessing utility, commodities derive their exchangeable value from two sources: from their scarcity and from the quantity of labor required to obtain them." Although he acknowledged that value could be determined by scarcity alone (e.g. rare documents), he felt that these were insignificant cases. His value theory therefore only applies to freely reproducible goods in competitive markets (Fogarty, 1996).

Through the $19^{\text {th }}$ century, Karl Marx (1818-1883) continued the value theory of Ricardo and developed his own view on the topic.

Fogarty (1996) also wrote the following:

According to Marx, the values of "All commodities are only definite masses of congealed labor time."... Like Aristotle, exchange of value or more appropriately exchange of 'just' value had for Marx, moral and judicial implications as well as economic ones. (Fogarty, 1996)

John Stuart Mill (1806-1873) relinquished the Classical-Ricardian view for a view of an absolute value-based on his understanding that "The value which a commodity will bring in any market is no other than the value which, in that market, gives a demand just sufficient to carry off the existing supply.". (Mill, 1909). The origins of modern utility theory can be traced back to William Jevons (1835-1882), with his Theory of Political Economy and Carl Menger's (1840-1921) of Principles of Economics. Fogarty (1996) wrote that "both developed the new tool of marginal analysis in 1871 as a means of understanding value." For the neo-classical school in the $1870 \mathrm{~s}$, the classical cost of the production theory of value was heavily contested. Neo-classical economists, like Jevons and Menger, developed their own marginal utility theory, which stated that "Value depends entirely on utility." They specified that, regardless of the costs of producing the goods, when traded on a market, the value becomes regulated by the expected utility of the buyer (Fogarty, 1996).

Alfred Marshall (1842-1924) combined all classical views on value, with the marginal utility theory, and described value as the result of supply and demand. Fogarty (1996) noted the following about Marshall:

In general, however he felt that it was fruitless to argue whether demand or supply determines value as "we might as reasonably dispute whether it is the upper or under blade of a pair of scissors that cuts a piece of paper, as whether value is governed by utility or costs of production.". Any attempt to find one single cause of value as others had unsuccessfully attempted in the past, were doomed to failure. (Fogarty, 1996).

The following is from Wikipedia (Apr 4, 2016) on the Austrian School of economic thought:

The Austrian School is a school of economic thought that is based on the concept of methodological individualism - that social phenomena result from the motivations and actions of individuals. It originated in the late-19th and early-20th century Vienna with the work of Carl Menger, Eugen Böhm von Bawerk, Friedrich von Wieser, and others....Current-day economists working in this tradition are located in many different countries, but their work is referred to as Austrian economics. Among the theoretical contributions of the early years of the Austrian School are the subjective theory of value, marginalism in price theory, and the formulation of the economic calculation problem, each of which has become an accepted part of mainstream economics. Many economists are critical of the current-day Austrian School and consider its rejection of econometrics and aggregate macroeconomic analysis to be outside of mainstream economic theory, or "heterodox." Austrians are likewise critical of 
mainstream economics. Although the Austrian School has been considered heterodox since the late 1930s, it began to attract renewed academic and public interest starting in the 1970s. (Wikipedia - Austrian School , n.d.).

The following is from Wikipedia (Dec 26, 2015) on the subjective theory of value

The subjective theory of value is a theory of value which advances the idea that the value

a good is not determined by any inherent property of the good, nor by the amount of labor necessary to produce the good, but instead value is determined by the importance an acting individual places on a good for the achievement of his desired ends. While the modern version of this theory was created independently and nearly simultaneously by William Stanley Jevons, Léon Walras, and Carl Menger in the late 19th century it had in fact been advanced in the Middle Ages and Renaissance but did not gain widespread acceptance at that time. (Wikipedia - Subjective theory of value, n.d.).

In the late $20^{\text {th }}$ century, Georgescu-Roegen in his book, "The Entropy Law and the Economic Process", (Georgescu, 1971, p.287) defines value as a result of life enjoyment. His value theory acknowledges the value concept, from Ricardo through to Marx, by illustrating the concept of value theory with objective and exact equations, as derived from the physics entropy law.

"Value is a category which can change only with the advance of knowledge and which can be projected only on a dialectical scale of the order of importance." (Georgescu, 1971, p.287)

The concept of value was, and still is, in a constant state of development and refinement. The concept will evolve and transform alongside the development of human society. There is still no universal definition and understanding of it; only the constantly developing concept that is evolving alongside the development of human society.

When talking about the concept of value in today's business terms, it must be considered in relation to other concepts that have emerged out of the value theory for a better understanding as a whole. These other concepts include utility, marginal utility, and scarcity of a certain resource.

Value can be measured by defining aspects of the concept, the intrinsic objective value, and the value concept driven by subjectivity, utilitarianism, and importance. It can be observed that at the start, value was a more practical and objective concept that was driven by daily and simple human needs. The more human society evolves, basic needs are embraced and the value concept becomes more complex and more subjective. The measurement of value is debated as much as the differences in theories of the value concept, which attempt to attain complete and thorough understanding of value.

Over time, scholars and economists have attempted, foremost, to determine and define the value of goods or services for an individual. The concept of value for certain goods or services became more complex after it was linked to the exchange, because this approach introduced concepts like economic value, price, market price, and exchange price. Value is linked to price through the process of exchange of goods and services. The exchange of certain goods or services involves profiling a place of exchange, i.e. the market, as well as the market price and the involved parties in the exchange, i.e. the seller and buyer. Even though the concept of economic value is contiguous with market value and market price, it is not the same. Market price is defined by the price that enables the exchange of goods or services that are accepted by the seller and buyer, whereas market value is the value defined for the specific goods or services at an exchange that would be possible after considering competitive market conditions.

Economic value is one way of measuring value. In today's business terms, value is often associated with the amount paid for certain goods, services, or resources. It is associated with monetary worth or 
usefulness of a commodity, and thus, often referred to as economic value. Economic value is the expression of goods and services able to generate income and therefore able to facilitate an economic exchange process. The economic value is measured relative to money by the capability, ability, and willingness of a buyer to spend a certain amount to benefit from the specific goods or services.

\section{Value based management}

The main and fundamental purpose of any business organization is to create and assure value for its owner. Value creation and assurance can be granted through proper and adequate management of the business organization and its accessible assets and resources.

Value management and value-based management is a driver for business organizations and their executives in the $21^{\text {st }}$ century economy, which is based on information and knowledge.

Value is generated by a successful profitable organization, whereas economic value can be generated by the goods and services that are available and used for business purposes.

Value is therefore the prime commodity of the $21^{\text {st }}$ century, which is obtained by efficient management of information and knowledge, the basis for value management.

Koller (1994) wrote:

Value-based management can best be only understood as a sum of a value creation mindset and the management processes and systems needed to transform that mindset into action. Taken alone, either element is insufficient. Taken together, they can have a huge and sustained impact. (Koller, 1994). (p. 89)

The value creation mindset implies that senior managers and executives have a complete conscious understanding of the fundamental purpose of business, i.e. value creation for shareholders. Management processes and systems must be set up in a way that enables managers and employees to achieve maximum value for the organization. At the same time, incentives, compensation, and motivation within the organization should align with company strategies for the ultimate purpose of value creation.

Ogarc (2011) wrote the following:

The European standard definition (EN 12973 Value Management) of value-based management is as follows: "Value management is a management style designed to mobilize individuals, to developing skills and promoting synergies and innovation, aiming to maximizing the overall performance of an organization. Value management brings a new way to use many existing management methods. (Ogarc, 2011)(p. 2)

The change of management paradigm from revenue management to value-based management can significantly affect an organization and should be approached with great attention to an appropriate rate of change. Such a change in management paradigm is one of the most critical changemanagement processes for an organization, because of the deep implications and complexity of the business processes that are affected.

Capital structure and dividend policy are determined by how they create value for shareholders and are not aimed at increasing safety or revenue.

Ogarc (2011) wrote the following:

Measuring performance, setting targets and managers remuneration are closely linked to shareholder wealth change, rather than changing accounting income. Understanding the new management concept by the company requires solving educational and motivational challenges.

A culture change is necessary to achieve the company's main goal: maximizing 
shareholder wealth. Rehabilitation and change staff reward system is necessary for better implementation of this new concept of value-based management, oriented to obtain long-term value. (p. 2) (Ogarc, 2011).

\section{History of value-based management}

Value based management emerged and developed alongside the concept of value. In the early stages of development in the $19^{\text {th }}$ century value-based management was driven by the intrinsic and implicit value of the "industrial revolution", where development was based mostly on extensive investment in machines and hiring of staff. During this period, efficiency and productivity measures were created, developed, and implemented.

At the end of the $19^{\text {th }}$ and beginning of the $20^{\text {th }}$ centuries, Alfred Marshall stated that value can be understood as a synthesis between intrinsic value and the result of demand and supply and the thereof alignment of the buyers and supplier requirements. The resulting value-based management was becoming more complex by considering the market exchange process that determined the economic value and the increased need to quantify and measure it.

The scientific management of value had started, with more complex concepts emerged and become adopted. Concepts like ROI (Return of Investment), DCF (Discounted Cash Flow), residual income, transfer pricing, and time value of money built the ground stone of today's modern approach to value and value-based management. Peter Drucker in 1964 in his book "Managing for Results" describes "what to do" to achieve business success and increase shareholder value. In 1986, Alfred Rappaport published his work "Creating Shareholder value", which established him as one of the most important representatives of the creating-shareholder value mindset, which is the basis of today's value-based management.

The exact scientific and quantitative methods of the modern corporate finance world are dominated and driven by the World Wide Web business bubble that requires more precise and exact methods for business evaluation. Market Value Added (MVA), TSR (Total Shareholder Return), EVA (Economic Value Added), and CFROI (Cash Flow Return on Investment) are the tools that the mergers and acquisition (M\&A) industry used to evaluate their business transactions. At the same time, RAROC (Risk Adjusted Return on Capital) and other risk assessment methods emerged to provide assurance to that already developed and these involved scientific and economic quantitative methods. Balance Scorecard published by Kaplan and Norton at the end of the $20^{\text {th }}$ century was an addition to the already existing management concepts and added extra perspectives (customer, financial, business process, and learning and growth) to the implementation of the company's vision, mission, and strategy.

The beginning of the $21^{\text {st }}$ century was scarred with the end of the World Wide Web bubble and by several other corporate scandals, like the bankruptcy of Enron involving Arthur Andersen. This event put the scientific-developed quantitative methods under new examination and required introduction of new approaches towards the value and value-based management concepts.

Among the most prominent ideas to prevent further disasters in the future are listed by Value Based Management BV (valuebasedmanagement.net, 2016):

- Strict accounting practices and rules

- Improve corporate governance

- Separation of analyst from other banking activities

- More attention for business ethics and corporate social responsibility

- Rules for executive remuneration

- Protection of shareholder interests

- Attention to stakeholder interests 
- A long term view towards value creation

Value Based Management BV also published the following (valuebasedmanagement.net, 2016):

Despite their good intentions, many of these ideas also further increase the complexity of both internal and external environment of corporations, causing renewed interest to holistic value based management in corporations to support and ensure their core value creation processes.

In addition, Munteanu, Danaita, Hurbean and Bergler (2012) wrote the following:

Value based management represents a modern approach in the governance and steering of corporations, focused on value creation. The Chartered Institute of Management Accountants (CIMA) defines this concept as "a managerial process which effectively links strategy, measurement and operational processes to the end of creating shareholder value". VBM provides consistency of mission, strategy, culture, communication, organizational structures and decisions process, but most of all it enables performance measurement and alignment of the performance with reward and motivation instruments. This leads to concentration on three main components: creating value, managing for value and measuring value. Value based management generates long-term changes in the business processes, in the organizational values and in the manner of assuming responsibility. (p. 1) (Munteanu, Danaita, Hurbean, \& Bergler, 2012)

Value based management can focus on two different aspects that has gained more traction and interest in today's modern "new economy"; an economy that is based on knowledge and information.

Depending on the corporate purpose and the values prevailing in the business organization, the implementation of value-based management can differ among companies. The corporate purpose can be either economic (shareholder value) or aimed at other constituents directly (stakeholder value). After the 2008 economic crisis, the theory of value-based management for shareholder-value creation management is being held responsible for the inefficient erroneous approaches that led to the catastrophic outcome of the crisis.

Beck (2014) had summarized it as the following:

Many managers are caught in a dilemma: between a desire to maximize the value of their companies and the demands of 'stakeholder theory' to take into account the interests of all the stakeholders in a firm. The way out of the conflict lies in a new way of measuring value. (Beck, 2014)(p. 1)

Ciora and Robu (2010) had the following summary:

In times of uncertainty, knowing the best methods of measuring performance and creating value, determines the increase competitiveness of companies. By development of international markets and globalization, companies pursue entry in many national, regional or international markets. Competitiveness of companies is linked to performance; the latter can be presented by various methods, as this company must have a sustainable presence on the market. Performance and value creation concepts are common in company reports, but most often these concepts are not defined. Through this study, we highlight their importance and we measure this 
direct link between past performance and future value creation. (p. 1) (Ciora \& Robu, 2010)

Value Based Management BV published this:

Organizations serve a purpose. They exist to deliver a certain value. Organizations also

a tremendous amount of time, effort, investments, assets and resources. So it makes perfect sense to ensure, manage, monitor, encourage and support that maximum value is realized.(Jan 6, 2016) (valuebasedmanagement.net, 2016)

Martin and Petty (2001) summarized it this way:

Why do some firms create extraordinary value for shareholders, while others destroy it? A powerful suite of value based management tools can make the difference. Value based management (VBM) refers to tools that financial managers can use to plan, monitor, and control a firm's operations in ways that enhance shareholder value.... At its essence, value based management involves transforming behavior in a way that encourages employees to think and act like owners. Laying the foundation for building a capital market-focused measurement and reward system that ties employee-level performance to owner-level rewards, this book will help today's leaders establish a continuous cycle of value creation that benefits all stakeholders of a company. (p. 1) (Martin \& Petty, 2001)

\section{Discussions and Author's Opinion on the Concept of Value and Value Management}

The concept of value and, thereof, value management, has been, and will be, a concern for human society for a long time. These concepts have been evolving since the earliest trials of academics and scholars to define and disseminate a universally accepted theory. The development of the concepts, value and value management, has been driven by scientific breakthroughs in human social evolution. The development of the value concept, and thereof. value management, has possibly reached its limit of acceptability and validity as shown when applying the current value and value management concepts in the new evolved socially and economically evolved systems.

The 21 st century is defined and driven by a new type of "main commodity", involving data, information, and knowledge that each emerge with their own particular requirements that are new to the classical concepts of value and value management. These immaterial and intangible assets of the "new economy" have a major impact on the classic economical concepts, many of which need new interpretation and viewing through the perspective of the "new economy", which is economically driven by immaterial and intangible assets.

The classical view of value as the objective intrinsic value of constituents no longer applies in the context of the "new economy", with its immaterial and intangible drivers.

In addition, the new data- and information-driven economy cannot completely benefit from the subjective, utilitarian value theory. The intangibility of the main commodities of the "new economy", data and information, makes is difficult to assign "value" with a clear universal purpose. The utilitarian value concept in the context of the "new economy", i.e., the information economy, propels the concept of value to the limits of its validity and acceptability.

The foundation of the "new economy", which is the information economy, is represented by data and a high level of data summarization, i.e., information. Both elements are insufficient to validate the utilitarian value concept in the context of the new information economy.

The invalidation of the objective, intrinsic value theory and the partial validation and invalidation of the subjective, utilitarian value theory in the context of the 21 st century new-information-economy propels the concept of value, as currently understood, towards its limits of acceptability and validity. 
As Georgescu (1971) mentioned in his book "The Entropy Law and the Economic Process", value is one concept that can only evolve through knowledge, which adds the missing link to the concept of value in the context of the new-information economy.

Knowledge is the third element that joins data and information in their value context with value gaining, in this way, a uniqueness factor. Therefore, the utilitarian value theory is at least partially if not fully invalidated by knowledge, which has, as its main characteristic, unicity. From today's perspective, the classical concept of value is on the brink of the next major evolutionary step in matching current requirements and for universal acceptance.

The classical value management methods are at their limits of addressing intangible, immaterial commodities of the 21 st century new-information-economy. However, the first steps have been taken to capture the value of data and information; a certain form of quantification and tangibility has been assigned to immaterial and intangible commodities enabling the "materialization" and the use of the classical concepts of value and value management. These steps have been the storage of data in information management and storage systems. Patents have also been used to protect certain intangible and immaterial aspects of business. Nevertheless, the first steps of data "materialization" has only superficially dealt with what is known and accepted today as value and value management.

The limitations of the new-information-economy for classical concepts of value and value management is evident in the third level for summarizing data and information, i.e., knowledge.

In the philosophical sense, knowledge is determined by validity as the higher level of data and information summarization, whereas validity is determined by the higher level summarization of data, information. From today's perspective, by applying the classical value theory, one cannot completely value knowledge for its unicity.

Distortions in the classical value concept requires a new view for understanding value in a complete and integrated sense.

In some of today's well-known cases, there are serious distortions of value. These cases mainly query the true value of the goods or services provided.

\section{CASE of Oligopolistic or Monopolistic Markets}

Oil price is determined by monopolistic or oligopolistic markets, and the production cost, and delivery and sales costs, of crude oil is often far below the current selling price. Considering oil prices have dropped considerably in recent years without change in the demand for oil, the objective, intrinsic and utilitarian value theory appears invalid. The changes in price do not reflect the value of oil on the world market nor in demand or supply. Thus the question arises regarding the appropriate value theory concerning the market value of oil.

In tourism, rates vary for hotel rooms and due to the information technology, one can easily compare rates for the same hotel room. Often, the case of different rates for the same hotel room depends on the supplier or reseller. Both of today's known value theories are invalid or, at least, questioned in this case regarding the real value for the accommodation. In this case, knowledge could be the differentiator because of customers' familiarity with search engines that compare the different room rates to obtain the best offer.

\section{State Owned Organizations}

State-owned organizations and private businesses often compete for the same customers, with the same services or goods being provided. The only competitive advantage of the state-owned organizations is that they offer low prices. In this case, one ponders the actual value of the public health offer compared to that of the private owned health services. For a valid comparison, one needs to exclude the quality of the rendered services. The public health services are free for the customer because they are funded from the state budget, whereas in the private health services, each 
investigation service must be charged. Thus, the actual value of the rendered health services as judged by applying the classical value theory is unclear.

\section{Subsidized Goods and Services}

It is known that the Turkish tourism offer highly comparable or better rates than any other tourism offer. Their competitive advantage is the lower cost of tourism services compared to that of Europe. In this case, excluding labor rates, one ponders the value of the Turkish tourism services compared to their competition in Europe. Possibly, the preferential treatments, subsidies, and fiscal advantages are influencing the Turkish tourism services. Hence, the value of the services is unclear.

\section{Conclusion}

Value, value management, and the resulting valuation and or measurement of value have been central to the development of human society from its beginning. Value theory will continue to develop and to mirror the concerns of human society though time. The resulting and accompanying concepts like value-based management and measurement of value will synchronize with development alongside the value concept. Overall, value theory and its accompanying concepts and activities, like value-based management and measurement of value, will become more and more complex with time.

The value concept will need to change in today's new economy, which is based on information and knowledge. Any change of the value concept needs to reflect the latest "hard facts" of the new economy, and somehow reflect the subjective and objective value of information and knowledge.

There are more and more cases in the modern economies where following the value flow is not very easy. We have cases where distortions in the classical value theory are more and more obvious and evident especially when the requirements of the new information economy are influencing the economic reality.

The open points and future topics of research in this paper are the reflection of the value concept of the $21^{\text {st }}$ century in today's modern complex business organization where information and knowledge are prime "commodities". Within any business organization, there are direct and indirect activities, like production and support services. In the case of direct activities, the value concept, value-based management, and the measurement of the resulting value flows, as contributions to the business organization results, are easier to understand and implement. In the case of indirect activities, the contribution to the resulting value flows or the business organization is much more complex to understand, to implement and to show. However, ultimately, business activities need to comply and conform to the fundamental business goal of creating value for shareholders.

\section{References}

Beck, V. (2014). The effects of the implementation of value-based management. International Journal of Economic Sciences and Applied Research, 153-165. Retrieved 03 09, 2016, from http://ijbesar.teiemt.gr/docs/volume7_issue2/value_based_management.pdf

Ciora, C., \& Robu, V. (2010). Measuring Performance, Value Creation And Value-Based Management In The Context Of Competitiveness And Globalization. Annals of Computational Economics, 2(38). Retrieved 0309 , 2016, from http://feaa.ucv.ro/AUCSSE/0038v2-011.pdf

Fogarty, M. (1996). A History of Value Theory. Retrieved 02 21, 2016, from https://www.tcd.ie: https://www.tcd.ie/Economics/assets/pdf/SER/1996/Martin_Fogarty.html

Georgescu, N. R. (1971). The Entropy Law and the Economic Process. In N. R. Georgescu, The Entropy Law and the Economic Process (p. 457). Cambridge, Massachusetts, United States of America: Harvard University Press.

Koller, T. (1994). http://www.mckinsey.com/business-functions/strategy-and-corporate-finance/our-insights. Retrieved 03 09, 2016, from http://www.mckinsey.com: http://www.mckinsey.com/business-functions/strategyand-corporate-finance/our-insights/what-is-value-based-management 
Martin, J. D., \& Petty, W. J. (2001). Value Based Management: The Corporate Response to the Shareholder Revolution. United Kingdom: Oxford University Press. Retrieved 03 09, 2016, from https://ideas.repec.org/b/oxp/obooks/9780875848006.html

Mill, J. S. (1909). Principles of Political Economy with some of their Applications to Social Philosophy. (W. J. Ashley, Editor) Retrieved 06 30, 2016, from http://www.econlib.org/library/Mill/mlP31.html

Munteanu, V., Danaita, D., Hurbean, L., \& Bergler, A. (2012). The Value-Based Management Approach: From The Shareholder Value To The Stakeholder Value. Proceedings of the INTERNATIONAL MANAGEMENT CONFERENCE. 6(2012), pp. 39-44. Bucharest: Academy of Economic Studies. Retrieved 03 09, 2016, from http://conference.management.ase.ro/archives/2012/pdf/4.pdf

Ogarc, A. (2011, 05). Value-Based Management - Management System Of Modern Economy. Annals of Computational Economics, 2(39), pp. 147-150. Retrieved 03 09, 2016, from http://feaa.ucv.ro/AUCSSE/0039v2-017.pdf valuebasedmanagement.net. (2016, January 06).

http://www.valuebasedmanagement.net/faq_why_value_based_management.html. Retrieved 03 09, 2016, from http://www.valuebasedmanagement.net/: http://www.valuebasedmanagement.net/

Wikipedia - Austrian School . (n.d.). Retrieved 02 23, 2016, from Wikipedia: https://en.wikipedia.org/wiki/Austrian_School

Wikipedia - Subjective theory of value. (n.d.). Retrieved 02 23, 2016, from Wikipedia: https://en.wikipedia.org/wiki/Subjective_theory_of_value 